\title{
An investigation on different factors influencing firm's value: Evidence from Tehran Stock Exchange
}

\author{
Hassan Ghodrati ${ }^{\mathrm{a}^{*}}$ and Seyed Reza Ghazi Fini ${ }^{\mathrm{b}}$
}

\begin{abstract}
${ }^{a}$ Associate Professor at Faculty of Accounting and Management, Kashan Branch, Islamic Azad University, Kashan, Iran ${ }^{b}$ Accounting and Management, Kashan Branch, Islamic Azad University, Kashan, Iran

C H R O N I C L E

Article history:

Received July 28, 2013

Received in revised format

20 November 2013

Accepted 4 January 2014

Available online

February 102014

Keywords:

The value of the firm

Profitability components

Cash condition

Management efficiency

\section{A B S T R A C T}

This paper presents an empirical investigation to evaluate the relationship among firms' performances including cash, management efficiency and profitability. The proposed study considers eight components of current ratio, acid-test ratio, properties turnover, receivables collection period, earnings per shares, assets flow, return on assets and return on equities. The study selects some firms from Tehran Stock Exchange over the period 2007-2011. Using Spearman correlation ratio as well as regression technique, the study has determined that there was a weak and positive correlation between cash conditions and the firms' value. In addition, there is a reverse relationship between receivables collection period and the firms' value. The study has also found some weak relationship between firms' value and other management efficiency components. Finally, the study has detected some weak and direct relationship between the profitability and firms' value.
\end{abstract}

\section{Introduction}

The firm value is one of the most determinants of shareholder's wealth criteria used for management decision-making issues and it influences on the investor's behavior. Performance measurement of any financial firms plays an important role among most investors on making long-term financial decisions and it can be accomplished through various techniques such as econometric method, which investigates the relationship between firms' financial performance and firm's value. One of the problems for this evaluation is the firm's value measurement, which is based on book-value, fairvalue, equity etc. When the performance of various firms is compared, we need to consider firms' characteristics such as technology, life cycle, etc. Therefore, it is sometimes a difficult task to measure the performance of the firms, properly and, in this paper, we look for measuring the fairvalue of the firms without measuring the fair-value of firms' assets by determining appropriate

*Corresponding author.

E-mail addresses: d.ghodrati42@yahoo.com (H. Ghodrati) 
criteria. In this research, stock price along with debt book value are considered as fair-value of firm's assets. This criterion is measured firm's value. Performance evaluation normally is performed either quantitatively or based on process evaluation. The first method uses financial ratio for performance measurement while the econometrics methods use mathematical modeling, regression techniques, etc. Quantity performance methods can be defined as the ratio of output on input and performance index is used for criteria evaluation. Dong and Su (2010) reported that working capital management could influence the firms' profitability and liquidity by investigating the performance of some firms listed in Vietnam stock exchange over the period 2006-2008. They concentrated on different variables including profitability, conversion cycle and its related elements and the relationship that existed among them. They reported that the relationships among these variables were strongly negative, which indicates that a decrease in the profitability occurs due to an increase in cash conversion cycle. They also reported that if the number of days of account receivable and inventories were diminished, the profitability would increase the numbers of days of accounts receivable and inventories. Mohamad and Saad (2010) worked on crating the relationship between working capital management and performance of 172 selected Malaysian companies by investigating the relationship between market valuation and profitability over the period 2003-2007. They reported that there was a negative relationship between working capital variables and the firm's performance.

Chatterjee (2010) performed a survey on the importance of the fixed and current assets in the successful running of any business unit by looking into direct impacts of profitability liquidity. There have been a phenomenon observed in the business that most of the firms increase the margin for the profits and losses because this act shrinks the size of working capital relative to sales. When firms wish to increase or to improve their liquidity, they need to increase the working capital. Therefore, organizations have to lower their sales, which influence the profitability. They studied 30 United Kingdom based firms listed in the London Stock exchange over the period 2006-2008 and analyzed the effects of the working capital on the profitability. Mathuva (2009) studied the effect of working capital management on the performance on listed firms in Nairobi Stock Exchange over the period 1993-2008 and reported various findings. First, there was a negative relationship between the time when the cash was collected from the customers and the firm's productivity. This means that firms with more profit has less time to collect cash from the customers. In addition, there was a positive relationship between the inventories when they were brought in and the period in which they were sold and the firm's profitability. They also found some positive relationship between the average payment period and profitability. Sen and Eda (2009) performed an investigation on some selected firms on Istanbul Stock Exchange. They reported an increase on the productivity of the firm positively influence the firm's performance.

Terual and Martinez-Solano (2007) performed a survey on some small and medium sized Spanish firms over the period 1996-2002 and reported a negative relationship between the profitability of SME's and the number of days account receivable and days of Inventory. Ganesan (2007) selected 349 telecommunication equipment firms to study the effectiveness of working capital management over the period 2001-2007. They reported that days of the working capital negatively could influence on the profitability of these firms but in reality it did not affect the transportability of firms in telecommunication equipment industry. Sayaduzzaman (2006) examined that the management of British American Tobacco was highly reasonable due to the constructive cash inflows, designed approach in running the major components of working capital by evaluating five years data from 1999-2000 to 2002-2003. Appliance of multi-dimensional modal of existing assets mix may have optimistic impact on the nonstop expansion \& extension of this multinational enterprise. This also depends on collaboration of the stakeholders and business environment in the framework of globalization. Filbeck and Krueger (2005) investigated one some selected data of 26 industries by looking into the data of 970 companies over the period 1996-1999. They found out that firms were able to decrease financing cost and/or augment the funds obtainable for development by reduce the amount of funds attached to the current assets. They disclosed some significant difference between 
industries in working capital measures across time. In addition, they determined that these measures for working capital vary extensively with in industry with the passage of time.

\section{Research Hypothesis}

The main hypothesis of this paper studies the relationship between financial firm performances with its value. There are also three sub-hypotheses as follows,

1. There is a relationship between firm liquidity situations with its value.

2. There is a relationship between firm productivity situations with its value.

3. There is a relationship between firm profitability situations with its value.

Concerning the goal, the present research is applied; concerning inference, it is deductive. Furthermore, concerning research plan it is classified as ex post facto research, which is based on past information and historical observed data. Also concerning variables, data and quantities analytical measures, it is quantities and non-judgmental because a mathematical algorithm and modeling method is used. The statistical community consists of corporations accepted in Tehran Stock Exchange but it does not consist of financial intermediaries. In our selection strategy, there is no long interruption permitted for trading the shares of the firms. In addition, there were not permitted to change their fiscal calendar. To state the sample size, the general Cochran formula was used, so considering this formula and using random sampling method, 46 corporations were selected as sample size of this research. The financial of these firms was studied over the period 2007-2011 financial years. Therefore, the statistical community consists of 230 year-firms. The research general relationship is stated as this formula:

$y=f\left(x_{1}, x_{2}, x_{3}, x_{4}, x_{5}, x_{6}, x_{7}, x_{8}\right)$

where $y$ represents the firm value as dependent variable, $x_{1}$ to $x_{8}$ are earnings per share, Return on Investment (ROA), Return on Equities (ROE), Current ratio, Rapid ratio, Goods flow ratio, receivable collection period and Assets flows, which are considered as independent variables. The study uses linear regression technique to study the relationship between independent and dependent variables as follows,

$y=\propto+\beta_{1} x_{1}+\beta_{2} x_{2}+\beta_{3} x_{3}+\beta_{4} x_{4}+\beta_{5} x_{5}+\beta_{6} x_{6}+\beta_{7} x_{7}+\beta_{8} x_{8}$

where

$y=$ firm's value $=($ average of number share $\times$ share price $)+$ book value of liabilities

$x_{1}=$ Earn Per Share $=($ Net profit - preferred stock earn $) /$ average of number share

$x_{2}=$ Return on Assets $=$ Net profit $/$ Total Assets

$x_{3}=$ Return on Equity $=$ Net profit/Equity

$x_{4}=$ Liquidity ratio $=$ Current assets $/$ current liabilities

$x_{5}=$ Quick ratio $=($ Current assets - Inventories $) /$ current liabilities

$x_{6}=$ Goods flow ratio $=$ Net sales $/$ Inventories

$x_{7}=$ Assets Flow Ratio $=$ Net sale $/$ Total Assets

$x_{8}=$ Receivable collection period $=($ Receivable account $) /($ daily sales $)$

\section{Foundlings}

The historical data about Iranian corporation were collected and statistical calculations were computed. In this research, firm's value was calculated based on current value of firm's shares plus book value of its liabilities as a dependent variable. The earn per share (EPS), Return To Assets(ROA), Return To Equity (ROE), Current ratio, Quick ratio, Assets flow, Inventories flow, 
receivable collection period were calculated as in-dependent variables. Based on post researches, the multi-variables linear-regression was used for relationship variables evaluation. Table 1 demonstrates some basic information including mean, standard deviation, skewness and kurtosis.

Table 1

Summarize of variables Description

\begin{tabular}{lcccc}
\hline Variable & Mean & St. d Deviation & Skewedness & Kurtosis \\
\hline Earnings Per Share(EPS) & 612 & 831 & 2.89 & 16.96 \\
Return On Assets(ROA) & 8.81 & 9.75 & 0.05 & 2.85 \\
Return On Equity(ROE) & 22.95 & 51.76 & -3.85 & 24.46 \\
Current ratio & 2.22 & 7.00 & 8.01 & 69.46 \\
Acid-test ratio & 0.77 & 0.24 & 0.23 & -0.00 \\
Inventory turnover & 8.78 & 15.73 & 7.40 & 65.68 \\
Receivables collection period & 150 & 98.41 & 1.55 & 4.18 \\
Assets flow & 0.99 & 0.81 & 6.25 & 57.93 \\
Firm's value & 897 & 1548 & 3.28 & 11.79 \\
\hline
\end{tabular}

In order to make sure that all data are normally distributed, the study considers Skewedness and Kurtosis coefficients and Kolmogorov's test. As we can observe from the results of Table 1, the skewedness coefficients of variables are 3.28, 2.89, 0.05, -3.85, 8.01, 0.23, 7.39, 1.55, and 26.25. Therefore, except ROA, others variables are significant and Asymmetric. The Kurtosis coefficients of variables are $11.79,16.96,2.85,24.46,69.46,-0.0001,65.68,4.18,57,93$. These coefficients except for quick ratio are suitable and they are abnormal. The significance level of Kolmogorov test was near to zero and based on this significance level the normality of variables, especially dependent variable, is rejected. The logarithm convention was used for variables normalized. After normalized convention normality analysis was repeated. Nevertheless, the variables distributions were not became normal.

In addition to normality test, all of independent variables for linear regression analysis must be having independency from each other. Pearson correlation analysis was used to determine whether the data independent or not. Table 2 summarizes Pearson correlation analysis and all correlation coefficients are significance. However, the correlation coefficients for variables are generally less than 0.5 and then there is a week linear relation between in-dependents variable.

Table 2

Pearson Correlation for variables

\begin{tabular}{|c|c|c|c|c|c|c|c|c|c|}
\hline Variable & $\mathrm{X}_{1}$ & $X_{2}$ & $X_{3}$ & $X_{4}$ & $X_{5}$ & $\mathrm{X}_{6}$ & $X_{7}$ & $\mathrm{X}_{8}$ & $\mathrm{y}$ \\
\hline$\overline{X_{1}}$ & 1 & & & & & & & & \\
\hline $\begin{array}{l}X_{2} \\
\text { P-value }\end{array}$ & $\begin{array}{c}0.690 \\
0\end{array}$ & 1 & & & & & & & \\
\hline $\begin{array}{l}\mathrm{X}_{3} \\
\text { P-value }\end{array}$ & $\begin{array}{c}0.357 \\
0\end{array}$ & $\begin{array}{c}0.459 \\
0\end{array}$ & 1 & & & & & & \\
\hline $\begin{array}{l}\mathrm{X}_{4} \\
\mathrm{P} \text {-value }\end{array}$ & $\begin{array}{c}0.344 \\
0\end{array}$ & $\begin{array}{l}0.165 \\
0.012\end{array}$ & $\begin{array}{l}0.079 \\
0.234\end{array}$ & 1 & & & & & \\
\hline $\begin{array}{l}\mathrm{X}_{5} \\
\mathrm{P} \text {-value }\end{array}$ & $\begin{array}{l}0.119 \\
0.072\end{array}$ & $\begin{array}{c}0.312 \\
0\end{array}$ & $\begin{array}{l}0.048 \\
0.466\end{array}$ & $\begin{array}{l}0.120 \\
0.070\end{array}$ & 1 & & & & \\
\hline $\begin{array}{l}X_{6} \\
\text { P-value }\end{array}$ & $\begin{array}{l}0.090 \\
0.172\end{array}$ & $\begin{array}{c}0.259 \\
0\end{array}$ & $\begin{array}{l}0.114 \\
0.085\end{array}$ & $\begin{array}{c}-0.013 \\
0.842\end{array}$ & $\begin{array}{l}0.154 \\
0.020\end{array}$ & 1 & & & \\
\hline $\begin{array}{l}\mathrm{X}_{7} \\
\text { P-value }\end{array}$ & $\begin{array}{c}-0.318 \\
0\end{array}$ & $\begin{array}{c}-0.451 \\
0\end{array}$ & $\begin{array}{c}-0.312 \\
0\end{array}$ & $\begin{array}{c}-0.006 \\
0.933\end{array}$ & $\begin{array}{l}0.074 \\
0.261\end{array}$ & $\begin{array}{c}-0.255 \\
0\end{array}$ & 1 & & \\
\hline $\begin{array}{l}\mathrm{X}_{8} \\
\mathrm{P} \text {-value }\end{array}$ & $\begin{array}{l}0.191 \\
0.004\end{array}$ & $\begin{array}{c}0.414 \\
0\end{array}$ & $\begin{array}{l}0.184 \\
0.005\end{array}$ & $\begin{array}{l}0.031 \\
0.639\end{array}$ & $\begin{array}{l}0.112 \\
0.090\end{array}$ & $\begin{array}{c}0.780 \\
0\end{array}$ & $\begin{array}{c}-0.450 \\
0\end{array}$ & 1 & \\
\hline $\begin{array}{l}\mathrm{Y} \\
\mathrm{P} \text {-value }\end{array}$ & $\begin{array}{c}0.719 \\
0\end{array}$ & $\begin{array}{c}0.495 \\
0\end{array}$ & $\begin{array}{l}0.226 \\
0.001\end{array}$ & $\begin{array}{l}0.184 \\
0.005\end{array}$ & $\begin{array}{l}0.101 \\
0.127\end{array}$ & $\begin{array}{l}0.053 \\
0.423\end{array}$ & $\begin{array}{c}-0.286 \\
0\end{array}$ & $\begin{array}{l}0.156 \\
0.018\end{array}$ & 1 \\
\hline
\end{tabular}

As we can observe from the results of Table 2, there are no strong relationships among independent variables and we can make sure that there would no co-linearity issue. Table 3 demonstrates the results of regression analysis. 
Table 3

The summary of multi-variables linear-regression

\begin{tabular}{lccccccccc}
\hline $\begin{array}{l}\text { Method } \\
\text { Parameter }\end{array}$ & EPs & ROA & ROE & $\begin{array}{c}\text { current } \\
\text { ratio }\end{array}$ & $\begin{array}{c}\text { Rapid } \\
\text { ratio }\end{array}$ & $\begin{array}{c}\text { Inv. } \\
\text { flow }\end{array}$ & $\begin{array}{c}\text { Receivable } \\
\text { period }\end{array}$ & $\begin{array}{c}\text { Assets } \\
\text { flow }\end{array}$ & Constant \\
\hline common & 0.535 & 0.359 & 0.838 & -0.107 & 0.511 & 0 & -0.336 & 0.22 & 5.947 \\
standard & 0.271 & 0.128 & 0.265 & -0.030 & 0.120 & 0 & -0.173 & 0.072 & \\
\hline
\end{tabular}

The determinant coefficients for common and standard estimation were 0.368 and 0.345 , respectively. These coefficients show that the estimated equation had explained 36.8 and 34.5 percent of variables variations. Proximity of these coefficients to zero shows that the there was a week linear relationship between financial performances criterion with firm's value. Based on sign of parameters estimated can be concluded that:

a) There is a direct relationship between ROA, EPS, ROE, quick ratio and assets flow with firm's value. Therefore, by increasing the amount of these variables, the amount of the firm's value is increased. Because the relate parameters on regression estimation are positive.

b) There is a reverse relationship between current ratio and receivable collection period with firm's value. Therefore, by increasing the amount of these variables, the amount of the firm's value is decreased. Because the relate parameters on regression estimation are negative.

c) There is not any relationship between Inventories flow with firm's value. Therefore, by increasing the amount of this variable, the amount of the firm's value is not changed. Because was related parameter on regression estimation is near to zero. For extrapolation of these results the Fisher test was used. The results of Fisher test was showed on Table 4:

\section{Table 4}

Fisher's Test Results

\begin{tabular}{cccccc}
\hline Description & Squares & d.f & Mean of Squares & F-statistic & Sig. level \\
\hline Estimated & 328.33 & 8 & 4.166 & 16.053 & 0.00 \\
Remained & 57.353 & 221 & 0.260 & & \\
\hline Total & 90.681 & 229 & & & \\
\hline
\end{tabular}

The amount of significance level on this table is near to zero. Therefore, the relationship between research variables is extra palatable. At the nineteen and nine percent confidence level, the relationships among variables are accepted. Note that, our survey did not indicate that the data were normally distributed. Therefore, we need to also look at non-parametric analysis. Table 5 shows the results of our survey.

Table 5

Non-parametric correlation analysis

\begin{tabular}{|c|c|c|c|c|c|c|c|c|c|}
\hline Variable & $\mathrm{X}_{1}$ & $X_{2}$ & $X_{3}$ & $X_{4}$ & $\mathrm{X}_{5}$ & $\mathrm{X}_{6}$ & $\mathrm{X}_{7}$ & $\mathrm{X}_{8}$ & $\mathrm{y}$ \\
\hline $\mathrm{X}_{1}$ & 1 & & & & & & & & \\
\hline $\begin{array}{l}\mathrm{X}_{2} \\
\text { P-value }\end{array}$ & $\begin{array}{c}0.780 \\
0\end{array}$ & 1 & & & & & & & \\
\hline $\begin{array}{l}\mathrm{X}_{3} \\
\mathrm{P} \text {-value }\end{array}$ & $\begin{array}{c}0.682 \\
0\end{array}$ & $\begin{array}{c}0.676 \\
0\end{array}$ & 1 & & & & & & \\
\hline $\begin{array}{l}\mathrm{X}_{4} \\
\mathrm{P} \text {-value }\end{array}$ & $\begin{array}{l}0.212 \\
0.001\end{array}$ & $\begin{array}{c}0.421 \\
0\end{array}$ & $\begin{array}{c}-0.026 \\
0.697\end{array}$ & 1 & & & & & \\
\hline $\begin{array}{l}\mathrm{X}_{5} \\
\text { P-value }\end{array}$ & $\begin{array}{c}0.240 \\
0\end{array}$ & $\begin{array}{c}0.386 \\
0\end{array}$ & $\begin{array}{l}0.004 \\
0.949\end{array}$ & $\begin{array}{c}0.727 \\
0\end{array}$ & 1 & & & & \\
\hline $\begin{array}{l}X_{6} \\
\text { P-value }\end{array}$ & $\begin{array}{c}0.245 \\
0\end{array}$ & $\begin{array}{l}0.130 \\
0.050\end{array}$ & $\begin{array}{c}0.265 \\
0\end{array}$ & $\begin{array}{c}-0.301 \\
0\end{array}$ & $\begin{array}{l}0.112 \\
0.091\end{array}$ & 1 & & & \\
\hline $\begin{array}{l}\mathrm{X}_{7} \\
\text { P-value }\end{array}$ & $\begin{array}{c}-0.337 \\
0\end{array}$ & $\begin{array}{c}-0.425 \\
0\end{array}$ & $\begin{array}{c}-0.308 \\
0\end{array}$ & $\begin{array}{c}0 \\
0.996\end{array}$ & $\begin{array}{l}0.129 \\
0.051\end{array}$ & $\begin{array}{c}-0.398 \\
0\end{array}$ & 1 & & \\
\hline $\begin{array}{l}\mathrm{X}_{8} \\
\text { P-value }\end{array}$ & $\begin{array}{c}0.389 \\
0\end{array}$ & $\begin{array}{c}0.333 \\
0\end{array}$ & $\begin{array}{c}0.346 \\
0\end{array}$ & $\begin{array}{l}-0.53 \\
0.422\end{array}$ & $\begin{array}{l}0.020 \\
0.762\end{array}$ & $\begin{array}{c}0.685 \\
0\end{array}$ & $\begin{array}{c}-0.688 \\
0\end{array}$ & 1 & \\
\hline $\begin{array}{l}\text { Y } \\
\text { P-value }\end{array}$ & $\begin{array}{c}0.775 \\
0\end{array}$ & $\begin{array}{c}0.581 \\
0\end{array}$ & $\begin{array}{c}0.441 \\
0\end{array}$ & $\begin{array}{c}0.191 \\
0\end{array}$ & $\begin{array}{c}0.231 \\
0\end{array}$ & $\begin{array}{c}0.271 \\
0\end{array}$ & $\begin{array}{c}-0.406 \\
0\end{array}$ & $\begin{array}{c}0.366 \\
0\end{array}$ & 1 \\
\hline
\end{tabular}


Based on the results of Table 5, we can conclude that there was a positive and direct relationship between profitability indices (ROA, ROE, and EPS) with firm's value. Because the correlation coefficients for these variables are positive and amount of them are from 0.5 to one. In addition, there was a weak direct relationship between liquidity indices (Current and Quick ratios) with firm's value. Because the correlation coefficients sign for these variables were positive and their amounts were close to zero. Finally, there was a weak and direct relationship between some of productivity indices Inventories flow and assets flow with firm's value. Because the correlation coefficients sign for these variables are positive and their amounts are near to zero. There was a weak reverse relation between receivables collecting period and firm's value. Based on correlation and regression analysis it is concluded that, there was a relationship between financial performances with firm's value. The strong relationship between performances indices and firm's value was associated with profitability criteria.

\section{Conclusion}

In this research, 46 Iranian corporations were selected as random sample and their financial performances from 2007 to 2011 were investigated. The historical data of Iranian corporations were collected and statistical calculations were computed. In this research, firms' values were calculated based on current value of firms' shares plus book value of their liabilities as a dependent variable. The Earnings per share (EPS), Return on assets (ROA), Return on equity (ROE), Current ratio, Quick ratio, Assets flow, Inventories turnover, receivables collection period were calculated as in-dependent variables. Using some statistical observation, we have concluded that there was a direct relationship between ROA, EPS, ROE, Quick ratio and assets flow with firms' value. In addition, there was a reverse relationship between current ratio and receivables collection period with firms' values. However, there is not a meaningful relationship between Inventories turnover with firm's value. The results of non-parametric tests were also similar.

\section{References}

Chatterjee, S. (2010). The impact of working capital management on the profitability of the listed companies in the London stock exchange. Available at SSRN 1587249.

Dong, H. P., \& Su, J. T. (2010). The relationship between working capital management and profitability: a Vietnam case. International Research Journal of Finance and Economics, 49, 5967.

Filbeck, G., \& Krueger, T. M. (2005). An analysis of working capital management results across industries. American Journal of Business, 20(2), 11-20.

Ganesan, V. (2007). An analysis of working capital management efficiency in telecommunication equipment industry. Rivier academic journal, 3(2), 1-10.

García-Teruel, P. J., \& Martínez-Solano, P. (2007). Effects of working capital management on SME profitability. International Journal of Managerial Finance,3(2), 164-177.

Mathuva, D. (2009). The influence of working capital management components on corporate profitability: a survey on Kenyan listed firms. Research Journal of Business Management, 3(1), 111 .

Mohamad, N. E. A. B., \& Saad, N. B. M. (2010). Working capital management: The effect of market valuation and profitability in Malaysia. International Journal of Business and Management, 5(11), 140-147.

Sayaduzzaman, M.D. (2006). Working Capital Management: A case study on British American Bangladesh Company Ltd. The Journal of Nepalese Business studies. 3(1), 78-84.

Sen, M., \& Eda, O.R.U.C. (2009). Relationship between efficiency level of working capital management and return on total assets in ISE. International journal of Business and Management, 4(10), 109-114. 